\title{
External and internal networks and access to HRD resources in small professional service firms
}

\author{
Ciara Nolan Dr \\ Technological University Dublin, ciara.nolan@tudublin.ie \\ Thomas Garavan \\ Edinburgh Napier University
}

Follow this and additional works at: https://arrow.tudublin.ie/buschmanart

Part of the Business Administration, Management, and Operations Commons, Entrepreneurial and Small Business Operations Commons, and the Human Resources Management Commons

\section{Recommended Citation}

Ciara T. Nolan \& Thomas N. Garavan (2019) External and internal networks and access to HRD resources in small professional service firms, Human Resource Development International, 22:5, 477-503, DOI:

$10.1080 / 13678868.2019 .1625853$

This Article is brought to you for free and open access by the School of Management at ARROW@TU Dublin. It has been accepted for inclusion in Articles by an authorized administrator of ARROW@TU Dublin. For more information, please contact arrow.admin@tudublin.ie, aisling.coyne@tudublin.ie,gerard.connolly@tudublin.ie.

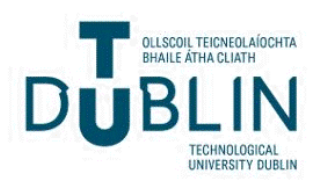




\section{Human Resource Development International}

\section{External and internal networks and access to HRD resources in small professional service firms}

\section{Ciara T. Nolan \& Thomas N. Garavan}

To cite this article: Ciara T. Nolan \& Thomas N. Garavan (2019) External and internal networks and access to HRD resources in small professional service firms, Human Resource Development International, 22:5, 477-503, DOI: 10.1080/13678868.2019.1625853

To link to this article: https://doi.org/10.1080/13678868.2019.1625853

曲 Published online: 04 Jun 2019.

Submit your article to this journal $\sqsubset$

Џll Article views: 654

Q View related articles $\asymp$

View Crossmark data \lceil

4 Citing articles: 3 View citing articles 준 


\title{
External and internal networks and access to HRD resources in small professional service firms
}

\author{
Ciara T. Nolan ${ }^{\mathrm{a}}$ and Thomas N. Garavan ${ }^{\mathrm{b}}$

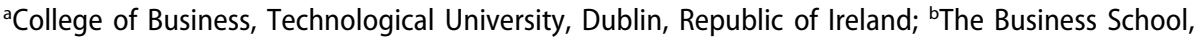 \\ Edinburgh Napier University, Edinburgh, Scotland
}

\begin{abstract}
A key challenge facing small professional service firms (PSFs) in the context of implementing human resource development (HRD) is access to resources. The use of external and internal networks represents an important means of identifying and acquiring needed resources. We utilize resource dependency and network theories to explore the types of networks used by ownermanagers to acquire HRD resources and the types of resources that are acquired. We investigate these issues utilizing three case study organizations located in the Republic of Ireland and interview data from owner-managers and employees. We found that small PSFs derived resources from both coercive and advisory external networks, in addition to a variety of internal networks including employees, personal contacts and interdependencies between owner-managers and employees. Different types of HRD resources included systemic, socio-political and strategic resources that helped them meet HRD priorities and goals. We discuss the implications for theory, research and practice.
\end{abstract}

\section{ARTICLE HISTORY}

Received 4 July 2018 Accepted 28 May 2019

\section{KEYWORDS}

Human resource development (HRD); small professional service firms; resource dependency and network theories; Republic of Ireland

\section{Introduction}

For small professional service firms (PSFs), human resource development (HRD) is considered critical to the development of inimitable, valuable human resources, which give these firms their competitive advantage (van Rooij and Merkebu 2015; Wapshott and Mallett 2013). HRD is increasingly proposed as vital to PSFs who provide services to clients in areas such as law, accounting, architecture, engineering, advertising and management consulting (Fu et al. 2015; Von Nordenflycht 2010). In this paper, we focus on management consulting, a rapidly growing global industry that is developing in importance and profile (Kipping and Clark 2012).

Small PSF owner-managers are typically confronted with significant resource constraints when it comes to HRD (Nolan and Garavan 2016; Short and Gray 2018). They are unlikely to have the advantage of a fully-fledged learning and development department and therefore owner-managers themselves will often be responsible for the development of employees (Fox 2013). In PSF settings, HRD activities are likely to be highly idiosyncratic. Studies suggest that HRD is strongly focused on-the-job, highly 
informal and experiential, reactive, potentially unsophisticated and in some cases, nonexistent (Dietz et al. 2006; Storey and Greene 2010). Morris $(2001,830$ ) highlights how the prevailing learning style of management consultants is 'active and experiential', with colleagues learning through the project-based collaborations in which they are involved. Hirschsohn (2008) found that small management consulting firms relied on a combination of ongoing, formal and informal HRD as it was deemed to be vital to their ongoing competitiveness and aspiration to remain at the cutting edge of developments in the field. Swart and Kinnie's (2003a) study of a small software engineering consulting firm also demonstrated that informal HRD processes can hold equal significance to formal practices when managing PSF workers. Their study found an interplay between written HR policies, informally embedded development processes used for sharing tacit knowledge, and important formal mechanisms for exchanging explicit information.

Consequently, both the work setting and the resource constraints in small PSFs are important in differentiating the nature and form of HRD from that found in larger PSFs. In addition, these resource constraints present small PSF owner-managers with significant challenges in how they undertake HRD in a context where the currency of knowledge and expertise is essential to the survival of these firms (Jørgensen and Becker 2015). The HRD priorities of small PSFs may therefore be dynamic and complex.

The liability of smallness (Welsh and White 1981) proposes that small PSFs may not have sufficient resources for HRD and this liability can create heavy dependencies on the effort, expertise and organizational connections that key external stakeholders and internal stakeholders such as employees, provide. Gibb (2009) highlighted the important role of stakeholders, including customers, suppliers, employees and regulatory agencies, to the survival and growth of small firms. Gibb argued that the effectiveness of a small firm is dependent on how well these network relationships are developed and maintained. Furthermore, Gibb (2000) affirmed that networks represent a key vehicle through which SME owner-managers develop required skills to manage the HRD process. Gibb (1993) also proposed that the ability of a small firm to manage 'know how' relationships provided an important resource for learning and development. In addition, a resource dependency perspective (RDT) (Pfeffer and Salancik 1978) suggests that in the context of small PSFs, dependency on these networks is central to achieve organizational goals (Voss and Brettel 2014). The liability of smallness thus suggests that the strategic use of resources through external and internal networks provides an important mechanism to realise HRD in these firms (Pfeffer and Salancik 1978).

Based on insights from network theorie and RDT, we propose that small PSFs can access and mobilize knowledge and expertise for the purposes of HRD and these networks can provide significant knowledge benefits to enable the development of employees. These network relationships will be both external to and within the PSF. Within the PSF, networks with employees, owner-managers and other personal contacts may serve as important sources of knowledge and resources to meet HRD requirements (Hite 2005; Ozcan and Eisenhardt 2009). Messersmith and Wales (2011) highlighted the important developmental resources that employees have to offer the small firm. Outside of the PSF, external networks of relationships with customers, suppliers, customers and regulatory bodies may act as vital conduits of knowledge and resources to achieve important HRD goals and priorities. In the context 
of small PSFs, scholars have highlighted the particular importance of relationships with clients (Fosstenløkken, Løwendahl, and Revang 2003), consultants and professional organizations (Wu, Bacon, and Hoque 2014).

However, while there is research highlighting the value of external and internal networks in the context of learning in small firms, there are a number of gaps in the literature. Saunders, Gray, and Goregaokar (2014), for example, found that small firms learn effectively from informal activities such as networking events, mentoring and coaching. Similarly, Leung et al. (2006) found that small firms are particularly reliant on knowledge and skill resources available through formal and informal networks. However, the key gaps in the literature in respect of PSFs and HRD include: (a) what are the different types of networks, both internal and external, that are important for HRD resources?; (b) what contribution do employees make and what is the role of the owner-manager in mobilizing interdependencies with employees?; and (c) what types of knowledge resources are generated from these networking activities in the context of HRD? We propose that the integration of RDT and network theories can help us to explore these questions. Network theories emphasize that the use of networks is key to helping small PSFs accumulate the resources necessary to achieve HRD goals and priorities. The RDT perspective focuses on the types of resources that are acquired through networking and the role of the owner-manager in managing dependencies with others who control important and needed resources (Hillman, Withers, and Collins 2009).

We explore these theoretical arguments in a study of owner-managers and employees in small management consulting firms. Our study makes three key contributions. First, we focus on small PSFs to achieve a more nuanced, systematic explanation of a particular type of SME network context and how this shapes HRD (Úbeda-García et al. 2013). We define a PSF as 'an organization that trades mainly on the knowledge of its human capital, that is its employees and the producer-owners, to develop and deliver intangible solutions to client problems' (Morris and Empson 1998, 610). Second, we specifically reveal the extensiveness of external and internal networks that small PSFs use for HRD resources and the types of resources they generate. We add nuance to current understanding by exploring the critical role of the client in the context of the small PSF and the salience of employees as an important internal network actor. Third, from a methodological perspective we investigate both owner-manager and employee perspectives. The paper is structured as follows. We begin by discussing the integration of RDT and network theories. We then outline the role of different networks and their resource contributions for HRD. Following this, we present our methods and describe how we collected the data. We report our findings and discuss the implications for HRD theory and practice in the small PSF context. We also acknowledge the limitations of the study.

\section{Theory development and literature review}

Successful resource accumulation is considered a critical activity for small PSFs in the context of meeting the HRD priorities of the firm ( $\mathrm{Wu}$, Bacon, and Hoque 2014). Therefore, small PSF owner-managers may need to interact with others that exist in their external and internal environment in order to gain access to resources for HRD (Pfeffer and Salancik 1978). RDT represents a useful theoretical lens for explaining the nature and success of these interactions for acquiring resources and focuses on how the 
owner-manager will manage dependencies with others who control vital and necessary resources (Hillman et al. 2009). This suggests that small PSFs will manage dependencies by either gaining access to resources that lessen their dependence on others or by gaining access to resources that increase others' dependency on them (Barringer and Harrison 2000). The nature of these dependency relationships gives rise to uncertainty, whereby critical resources are 'embedded in a complex network of interdependencies and varying levels of power' (Bendickson, Gur, and Taylor 2016, 3). HRD practices may therefore reflect the distribution of power among key network stakeholders (Kinnie, Swart, and Purcell 2005). RDT also emphasizes that owner-managers can exercise diverse strategic choices to manage interdependencies within the context of environmental constraints (Pfeffer and Salancik 1978).

Scholars have recently complemented RDT by integrating network theories to explain how small firms will manage their networks to enhance access to resources (Ahuja, Polidoro, and Mitchell 2009; Jack 2010). It is well established that networks extend the resource-base of small firms (Gordon and Jack 2010). However, the findings that emerge from this research suggest that a small PSF's ability to gain access to resources is dependent on the types of networks that are developed and the breadth of these networks (Hite 2005; Lin et al. 2009). We propose that it is important to understand who these external and internal networks are as a first step in developing an understanding of the role of networks generally in the small firm context as it applies to HRD. A central premise of network theories is that actors within a small PSF's network will offer differential access to different resources at different times (Mehra et al. 2006). We argue that the types of networks that small PSFs use will be relevant in understanding how they address changing resource dependencies and the types of HRD undertaken by the firm.

\section{External networks relevant to HRD}

Prior research examining the value of networks has found that the type of networks and with whom networks are developed are important issues (Chang 2004). This is especially true for small PSFs where there may be significant resource deficits when it comes to meeting employees' HRD needs. RDT proposes that different types of networks will help small PSFs to avail of unique opportunities and manage the uncertainty and varying resource needs in the context of evolving HRD needs and requirements. In particular, different networks will provide both different types and amounts of resources (Pfeffer and Salancik 1978), however, these networks may reduce the autonomy of the firm and its discretion in managing particular HRD issues. Network theories suggest that small firms should have a range of different external networks because it enhances the potential of the firm to have access to novel resources to solve particular HRD issues and help it respond to different and unique HRD resource needs (StorbergWalker and Gubbins 2007). Therefore, both RDT and network theories highlight the value of having a diverse set of external networks to maximize the resource exchanges that can take place. Such networks include (but are not limited to) clients, customers, suppliers and competitors, as well as trade unions, business associations, employees and the personal contact networks of owner-managers. These networks may be both formal 
and informal (Saunders, Gray, and Goregaokar 2014). We now discuss a number of these external networks.

\section{Clients}

A key actor in the small PSFs external network is the client (Fincham 2012). Swart and Kinnie (2003b, 37) observed that clients may seek to have a bigger influence on the HR systems of PSFs 'precisely because these practices are so critical to the skills and knowledge of their people'. They found that client influences were manifest directly, through client funding for HRD, the provision of resources in the form of training expertise or questioning suppliers about the nature and extent of HRD provision. Clients are also an important source of resources to conduct HRD. They have been identified as co-producers of HRD practices in management consulting firms (Broschak 2017). Awuah (2007) found that close and regular interaction with immediate customers in the firm's network context exerted a significant influence on competence development and enhanced the reliability and consistency of service provision. Anderson-Gough, Grey, and Robson (2000) also highlighted how PSF socialization processes are designed and driven by the imperative to be client-friendly. This suggests that ongoing HRD efforts represent attempts to shape employee behaviour and facilitate the acquisition of relevant knowledge to meet client demands (Jørgensen and Becker 2015). A significant study by Fosstenløkken, Løwendahl, and Revang (2003) suggested that client interaction is the single most important factor facilitating HRD in small consulting firms. Significantly, they found that employees may learn directly from knowledgeable clients, and that this learning can in turn trigger two further HRD processes: learning from peers in order to solve client problems and the development of collective firm knowledge through improve modes of service delivery. The latter points to the importance of having organizational mechanisms such as formal databases such as in place to capture learning from client relationships (Broschak 2017).

Client influences have been more commonly found to manifest indirectly, where HRD is geared towards enabling the firms to meet and anticipate the needs of a variety of clients (Kinnie et al. 1999). Client demands may therefore mandate new or alternative HRD arrangements (Susomrith and Coetzer 2015) and flexible HRD practices may be used to meet intense and turbulent market pressures (Úbeda-García et al. 2017). HRD often takes place due to a desire to improve product and service quality or standards, productivity, reputation and client satisfaction (Padachi and Bhiwajee 2016). Studies report that dominant large clients are likely to be a driving force for higher incidences of formal and sophisticated HRD approaches such as the adoption of the Investors in People (IIP) accreditation (Bacon and Hoque 2005; Wu, Bacon, and Hoque 2014).

\section{Advisory networks}

Advisory networks are another important external network actor in the context of HRD, although studies pertaining to HRD explicitly are relatively scant. However, a recent study by Hubner and Baum (2018) found that small firms rely heavily on such networks in the direct provision of HRD for employees. Significantly, studies have found that not only do networked firms provide more HRD opportunities for employees, but membership of multiple business advisory networks is particularly crucial and 
positively associated with the intensity of HRD evident in the firm (Erickson and Jacoby 2003; Hoque and Bacon 2006). Klaas et al. (2012) also maintain that owner-managers may be predisposed to adopt more strategic approaches to HRD as a result of network participation.

Analysis of the WERS survey data by Forth, Bewley, and Bryson (2006) found that SMEs are more likely than larger firms to seek advice relating to HRD issues. However, several studies have highlighted the lack of integration of SMEs into networks of advice and information which could enable them to develop their HRD practices (Gilman et al. 2002; Jones 2006). Bishop (2011) emphasized the central role of 'trusted contacts', informal relationships and sector-specific trade associations in terms of promoting positive attitudes amongst SMEs towards training and in shaping perceptions about the credibility and utility of external education and training providers. In addition, Doherty and Norton (2014) drew attention to the influence of network relationships between a case firm and the involvement of HR academics as part of a knowledge transfer partnership (KTP). The KTP played an important role in the firm's adoption and intensity of formal HRD programmes, as well as in the preparation of a strategic HRD plan.

\section{Internal networks relevant to HRD}

\section{Owner-managers}

In small PSFs, the HRD orientation of the owner-manager is vital in explaining the nature of HRD and its key characteristics in the firm (Barrett 2015). HRD orientation refers to systematic effort to develop a competent and committed workforce (Lam and White 1998). Indeed, it has been suggested that the experience, expertise and attitude of the SME owner-manager may exert a more powerful influence on HRD than the limitations attributed to resource constraints (Kroon, Van De Voorde, and Timmers 2013). While the role of the owner-manager has been highlighted, it is also important to acknowledge that in endeavouring to generate resources for HRD through multiple networks, owner-managers are faced with a range of pressures in the form of time, uncertainty and continuous change, which requires them to respond by making quick decisions (Tsai 2010). These pressures, in turn, exert an impact on internal organizational arrangements such as HRD policies and practices (Kinnie et al. 1999). Ownermanagers may therefore respond to evolving pressures by embracing informality as it provides their firms with much needed flexibility and responsiveness to adapt to environmental contingencies (Verreynne, Parker, and Wilson 2013). Despite the prominent role played by the owner-manager, the central role played by employees within the PSF setting and the degree of power they exercise over practices at the level of the firm must also be considered.

\section{Employees}

The role of the employee is highlighted as an important internal resource in the context of HRD. Within small PSFs, studies have found that the provision of HRD opportunities plays a vital role in eliciting employee commitment to delivering a high quality service to the client and can create a sense of obligation on the part of employees to reciprocate with behaviours that benefit the organization (George 2015; Giauque, 
Resenterra, and Siggen 2010; McClean and Collins 2011). A strong employee HRD orientation is therefore vital. Employee HRD orientation refers to employee efforts to engage in self-development to enhance their knowledge, skills and abilities (KSAs), master new situations, and improve their competence for their personal benefit and that of their firm (Vandewelle 1997). From an RDT perspective, high degrees of interdependency between owner-managers and valuable specialist employees suggest that small PSF employees are active agents who are involved in ongoing consultation about and delivery of HRD (Messersmith and Wales 2011; Wapshott and Mallett 2013).

The structure of work within small PSFs highlights the important role of employees as deliverers of HRD. For example, the nature of the work in consulting firms brings together different areas and levels of expertise to solve client problems via project-based teams (Maister 1993). This facilitates the transfer of valuable tacit knowledge from senior to junior consultants through informal interactions when completing client assignments (Hitt et al. 2001). Werr (2012) highlights other work structures that facilitate learning and development amongst consultants, including formal meeting structures such as brainstorming sessions or collective project debriefings that foster learning-oriented conversations upon the completion of client projects.

In order to utilize the employee as a resource for HRD purposes, owner-managers frequently employing a strategy of fraternalism (McClean and Collins 2011). An egalitarian management style is adopted and employee roles tend to be highly autonomous and discretion based, with employees afforded significant opportunities to contribute their development resources (Brown et al. 2010). Studies have also emphasized the importance of harnessing the discretionary effort, motivation and commitment of employees for effective knowledge sharing (Behrends 2007; Mallett and Wapshott 2014). In addition, Hargadon and Bechky (2006) draw attention to the heavy reliance amongst employees on their internal and external personal contact networks to find solutions to problems encountered in the context of PSF work.

\section{Research methodology}

\section{Sample and procedure}

In line with prior research on small PSFs (e.g. Ram 2000; Wapshott and Mallett 2013), we utilized an in-depth, qualitative, multiple case-study research strategy to address the research questions (Yin 2014). This approach was valuable in enabling us to gain a deep and rich understanding of the role that external and internal networks play in helping small PSFs to address their complex HRD priorities (Gray 2017; Henry and Foss 2015). It also allowed us to explore key issues in their natural setting, thereby preserving the wholeness, unity and integrity of the case context (Ridder, Hoon, and McCandless Baluch 2014).

In light of the relative lack of knowledge about networks and HRD resources in SMEs, the study utilized a purposeful approach to sampling; a common convention in qualitative research (Kuzel 1992; Patton 2002). As Patton $(1990,185)$ has observed:

The validity, meaningfulness, and insights generated from qualitative inquiry have more to do with the information-richness of the cases selected and the observational/analytical capabilities of the researcher than with sample size. 
In adopting this approach, we selected three cases that were 'information rich' and illuminative (Patton 2002). Following Ram, Woldesenbet and Jones (2011, 313) we secured access to the firms through the 'tried and trusted method' of personal contacts, which included management consultants known to the research team, trade associations and professional bodies. This approach also helped to overcome the scepticism amongst SMEs towards academic research and their dislike of a 'cold call' approach (Curran and Blackburn 2001).

The three firms shared a number of commonalities which permitted meaningful comparisons. Each of them were well established and employed less than 50 people, thus corresponding to the European Commission (2015) definition of a 'small firm'. They also met the key criteria of a PSF as defined by Morris and Empson (1998). The firms offered bespoke and off-the-shelf management consulting services to a diverse range of public and private sector clients. Their owner-managers were actively involved in HRD activities, strategically and at an operational level. The firms had also attained the Excellence Through People (ETP) certification, an Irish national business improvement framework similar to IIP. For reasons of confidentiality, the firms have been afforded pseudonyms.

\section{Operationalizing key concepts}

Building on the work of Drakopoulou Dodd and Patra (2002, 117), we conceptualized networks as 'the sum total of relationships in which the small PSF workforce participates, and which provide an important resource for firm activities'. These relationships may be articulated through the mechanism of membership in formal organizations, through the links developed with suppliers, distributors and customers, or through the utilization of social contacts, including acquaintances, friends, family and kin.

Recent thinking (Sung and Choi 2014) conceptualises HRD as a multidimensional construct and advocates the need to capture four key dimensions: qualitative, which includes managerial support for HRD and its perceived benefits; quantitative, which pertains to resource investments in HRD activity; as well as both managerial and employee perspectives. While conceptual confusion still surrounds HRD (Werner 2014), there is a broad consensus that its primary concerns surround the training and development efforts of organizations to enhance the task-related skills, competencies and knowledge of the workforce (Ghosh et al. 2014).

For the purposes of this study, there was also a need to operationalize HRD in a pragmatic and 'SME friendly' way (Cassell et al. 2002). Thus, in line with current thinking, we conceptualized HRD in a multidimensional manner. Participants were encouraged to discuss formal and informal HRD policies, practices and processes that enabled them to effectively carry out their current role, as well as preparing them for future organizational roles (Carbery 2015). Owner-managers were also encouraged to focus on their support for HRD, in financial terms and in terms of subjective endorsement, while employees were asked about their experiences in terms of satisfaction with HRD opportunities (Sung and Choi 2014). 


\section{Data collection}

The data was collected in each firm over a six-month period. The initial phase involved telephone and email conversations, followed by a site visit to discuss the research process with the study participants. The research team explained the purpose of the study and discussed issues of access to employees and company documentation. The second phase involved an intensive period of triangulated data collection (Denzin 1978) which included 20 face-to-face extensive semi-structured interviews with senior management personnel and employees, a review of company documentation (where available) and brief opportunities for observational research. The ownermanagers, whose titles varied from managing director to owner, were interviewed at all three firms. Seventeen employees across the case firms were also interviewed and these employees had varying levels of experience. The selection of employees for interview was made by the owner-managers, primarily based on who was available at the time of the site visit (cf. Harney and Dundon 2006). The final phase of data collection involved 9 follow-up interviews to obtain further information on key issues that arose during initial data coding and analysis and for clarification purposes. This third phase also afforded us the opportunity engage in member validation (Lincoln and Guba 1985) to ensure that our accounts accurately reflected participant experiences.

We adopted a semi-structured approach to the interview process as advocated by Patton (2002) and utilized an interview topic guide. This guide served as a basic checklist to ensure that all of the relevant topics and same key themes were discussed with each interview participant. It also afforded us the flexibility to pursue themes and issues that emerged during this process (Collis and Hussey 2014). The semi-structured interviews typically lasted approximately 50 minutes, ranging from 35 to 125 minutes. They were audiotaped and verbatim interview transcripts were produced to facilitate subsequent data analysis (Gray 2017). All interviews were structured around issues relating to the study's research questions, specifically the role that external and internal networks play in resourcing and influencing HRD in small PSFs. Participants were also prompted to consider particular pressures created by network actors and any potential tensions that emerged that impacted on decisions about HRD. Owner-managers were encouraged to discuss how they strive to manage multifaceted network influences when making decisions about best to address HRD priorities. All participants were also asked to discuss the nature of their business and the management consulting profession more generally.

\section{Data analysis}

Our data analysis process consisted of several stages. The aim of the first stage of data analysis was to allow the research team to become intimately familiar with each case as a stand-alone entity' (Eisenhardt 1989, 540). This process was highly iterative, with the research team going back and forth between interview transcripts and field notes, in conjunction with notes from field observations and those taken following each interview. The second stage of data analysis adhered to key principles advocated by Gioia, Corley, and Hamilton (2013). We developed first-order concepts using descriptions based on the language of the study participants. We also referred to the literature in order to help us identify a number of a priori codes to give the data some structure. 
While we expected that some codes would emerge based on the literature review, such as the perception that learning through client work is vital, other codes emerged from the data, such as the perception of advisory networks as a cost-effective means of HRD and the engagement of employee in extracurricular networking to meet both individual and firm-level HRD priorities.

In the third stage of data analysis, we focused on developing higher, second-order themes which focused on the relationships between the first-order concepts. The aim was to move to a higher level of abstraction to describe and explain the phenomenon under investigation (Miles and Huberman 1994). During the next stage of data analysis we focused on combining the second-order themes into second-order, theoretically relevant 'aggregate dimensions' (Gioia, Corley, and Hamilton 2013). Finally, we conducted cross-case analysis (Yin 2014) to explore similarities and differences in network resources and influences in addressing HRD priorities between the case firms. This allowed us to identify whether any particular patterns of network influences were prevalent and what factors might account for this. Figure 1 presents our data analysis structure, which represents a key component of demonstrating rigor in qualitative research (Pratt 2008).

\section{Robustness of findings}

Following Lincoln and Guba (1985), we took a number of steps to enhance the credibility of our findings. We adopted a methodological triangulation strategy (Denzin 1978) using methods such as in-depth interviews at different levels of the firm, site visits, follow-up telephone calls/emails to clarify issues observed and discussed, and opportunities for observational research. In addition, we reviewed

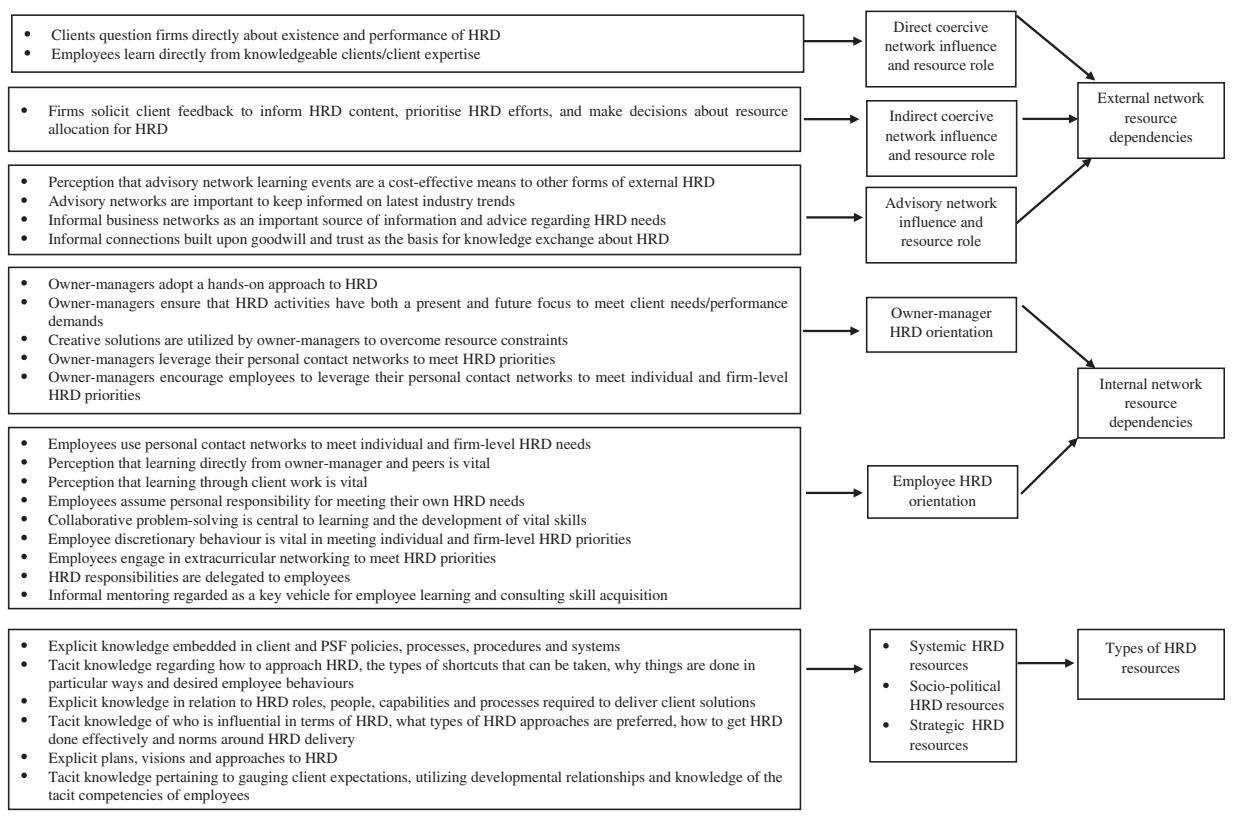

Figure 1. Data analysis structure. 
organizational documentation (where made available). Following Lawrence, Malhotra, and Morris (2012), only one of the authors was involved in the data collection process. The other author was a highly experienced qualitative researcher and they undertook an independent review of the interview and field notes. In order to verify the accuracy of our key findings, we also engaged in member validation (Lincoln and Guba 1985) and went back to the firms to ensure that our accounts resonated with their experiences.

\section{Findings}

\section{External networks and HRD resources}

A range of external actors exerted an influence on firm operations more generally and on HRD in particular. Owner-managers at the three firms spoke about how the Irish economic crisis had negatively impacted upon the business:

...the cost of the sale is higher, the work is harder and definitely people are still spending but it is definitely down. There is no doubt business is down (Owner-manager 1, PeopleCo).

\section{Clients}

Clients emerged from the data as particularly important in their influence and resource role in the context of HRD. Such influences were revealed as both direct and indirect in nature. Indirect client influences were strongly evident at all three firms and ownermanagers referred to the dynamic nature of client needs. Maintaining the currency of knowledge and skill levels to deliver solutions was therefore particularly crucial, which meant that HRD was a strategic priority for the firms, as well as an ongoing operational activity. Proactively soliciting feedback from clients, along with frequent client consultations, thus represented important resource inputs to prioritizing HRD efforts and helping the firms make important decisions regarding scarce resource allocation for HRD. At CommCo, one of the owner-managers highlighted the imperative to produce evidence-based client solutions, which required greater attention to research and keeping up-to-date with industry developments:

The two things that we are investing in this year are training and research. We have got to prep our people better so that they can give the best advice possible to clients (Ownermanager 2, CommCo).

Further evidence of indirect client influences was evident at PeopleCo whereby the need to enhance employee knowledge and learning had led to the introduction of a formal graduate training programme and an internship programme for junior consultants. CommCo had established an in-house training academy and empowered employees to take responsibility for its management. This included managing the budget, preparing training plans, sourcing courses and promoting training opportunities.

The direct role of clients was evident at PeopleCo, where an in-house, continuing professional development (CPD) programme had been established. Clients had expressed some concerns about the business acumen of junior consultants, which prompted the two owner-managers to create a new HRD strategy: 
This prompted myself and [the other owner-manager] to look at a way in which we could teach them some of the knowledge and expertise we would have and also make the guys and girls responsible for their own CPD (Owner-manager 2, PeopleCo).

A points-based CPD system was introduced and employees were required to report on their activity at monthly staff meetings and via the bi-annual formal performance review process. Employee reactions were very positive as the programme empowered them to play a proactive HRD role, enhanced their knowledge and skills and helped to create a more professional identity in the eyes of clients:

The concept of it is excellent, especially in a consultancy firm. You are meant to be ahead of your game. You are supposed to know in your topical area what is going on (Relationship manager, PeopleCo).

Further evidence of the direct role of clients was found at CommCo, where the ownermanagers made reference to clients demonstrating a keen interest in the training that was taking place:

Clients would ask us about training .... They are just interested that we are training our people and making sure that our people are keeping ahead of the curve. It is good for business (Owner-manager 1, CommCo).

In addition, the three firms had received ETP certification and owner-managers made reference to the impetus for seeking this certification as being largely driven by client performance demands:

It is a fantastic rigorous process ... it really forced us to systematically line up the ducks in a row. We felt that we needed to have it because to demonstrate to our clients that we walk the talk. (Owner-manager 2, PeopleCo).

The influence of client resource inputs was also manifest in the types of and approaches to HRD within the firms, with interventions often embedded within the context of project-based teamwork. At an operational level, learning through client work was deemed to be critical to the acquisition of a range of consulting skills. In particular, informal mentoring served as an important vehicle for employee learning and skill acquisition and owner-managers at all three firms were actively involved in the HRD process. A junior consultant at PeopleCo described the importance of working alongside the owner-manager:

[Owner-manager] has been great. She has let me come out on client meetings, sit in an observatory manner and I think that is a really good learning experience. I don't think any two meetings are the same, it is always different. It was great because the meetings were all at different stages of the consulting cycle. There was pre-proposal stage, proposal stage and presenting the proposal. It was a great experience.

At CommCo, employees also spoke about the value of client pitch simulations facilitated by the owner-managers which provided them with a forum to hone their consulting skills and develop professional confidence.

\section{Advisory networks}

Due to the nature of the work they undertook, the firms were members of or had relationships with a wide range of professional bodies and industry associations. These 
advisory networks included the Chartered Institute of Personnel and Development (CIPD), the Irish Institute of Training and Development (IITD), Skillnets, ${ }^{1}$ the Small Firms Association, SOLAS, ${ }^{2}$ the Public Relations Institute, the Sales Institute of Ireland and Dublin Chamber of Commerce (to name but a few). However, the influence of such networks on HRD was mixed. Owner-managers at PeopleCo and CommCo often utilized the networking events organized by these bodies as a cost-effective means of keeping informed on industry developments. They, along with MultiCo, also availed of subsidized and/or free learning opportunities for themselves and other employees on occasion as needs arose. On occasion, the firms approached professional bodies such as the CIPD directly, primarily in the context of sourcing a suitable external training or education programme for employees. The resource role of these advisory networks was therefore not particularly extensive, with all three firms utilizing them on an ad-hoc basis, as particular HRD needs arose.

Apart from business associations and professional bodies, other advisory networks played an important role in addressing HRD priorities. For example, PeopleCo had developed close links with a University in their local area and this relationship had yielded two key benefits: a pipeline of new recruits which reduced labour market pressures and the ability to tap into the expertise of academics regarding research trends. Informal business links, associates and personal networks also served as important sources of information and advice about HRD issues. At MultiCo, the owner-manager spoke about links with the owners of other local businesses, as well as a number of associate consultants, that he could call upon. This was echoed by the owner-managers of PeopleCo, who also emphasized the importance of maintaining informal connections built upon goodwill and trust as the basis for knowledge exchange about HRD issues.

\section{Internal networks and HRD resources}

\section{Owner-managers}

Owner-managers represented a vital resource for the design and delivery of HRD. Owner-managers admitted to experiencing challenges in trying to identify the most important HRD activities to focus on and the most appropriate methods to invest in. Consequently, the key to success was a matter of meeting the needs of current clients, while also anticipating future client needs in order to be one step ahead of both the client and competitors. HRD was therefore goal oriented and designed around the achievement of key business objectives identified by the owner-manager and pertaining to client performance demands:

Our clients dictate our innovation and where we direct our company (Owner-manager 1, PeopleCo).

I think we really have had to become very innovative and be very adaptable and quick on our feet in terms of reinventing (Owner-manager 2, PeopleCo).

Product market pressures in combination with financial resource constraints and work intensification had forced the firms to curtail their investment in external HRD. Despite this, employees emphasized their firms' willingness to invest in a wide range of opportunities for learning and professional development and attributed this to the 
values and passion of the owner-managers. However, owner-managers also highlighted how resource constraints meant that they had to employ a range of creative approaches to manage these constraints, including owner-managers and employees leveraging their personal contact networks. Owner-managers had also assumed a more extensive handson approach to HRD in terms of its delivery. By way of illustration, at both PeopleCo and CommCo, owner-managers delivered lunchtime seminars on a wide range of topics pertaining to effective client management. The owner-managers at PeopleCo and CommCo highlighted how employee participation in HRD was monitored informally during daily interactions and formally during staff meetings and the performance review process:

If someone has done no training I would be very keen to know why they didn't attend and what are they planning to do about it or do they care? If they didn't care it would be odd and not impressive (Owner-manager 1, CommCo).

\section{Employees}

Employees emerged as a particularly important resource in delivering HRD in the three case firms. These resource dimensions were revealed in a number of ways. At CommCo, for example, the employees with current responsibility for the training academy were making greater use of their own personal contact networks to 'call in a few favours' to source external speakers. In all firms, employees made extensive reference to learning from the owner-managers and colleagues and how it was incumbent upon them to assume individual responsibility for HRD. At MultiCo, the open plan nature of the office was also highlighted as a valuable means of social and experiential learning and solving problems collaboratively. Client problems frequently triggered discussions which enhanced learning:

You know exactly what's going on. If somebody has a problem, they say it out loud and we all discuss it and see what kind of approach we can come up with and we get a solution.

(Client manager, MultiCo).

Consensus on the importance of employee-driven contribution to learn and develop their KSAs was echoed by employees at PeopleCo and CommCo. Employees were keen to deliver a high quality service to clients by demonstrating discretionary effort:

...it's in your best interest to do things that are quirky or to do things that benefit the business. So say, of my own accord, I attend a lot of networking events to gain CPD points, but ultimately it's beneficial for me (Junior consultant, PeopleCo).

The desire to give something back to the firm was also evident in employee discussions pertaining to the requirement to share knowledge with others following participating in an external learning event. This often took the form of a presentation to colleagues during a meeting or the circulation of a document with key learning points. PeopleCo and CommCo had also created databases with a wide range of resources for employees to access as needed.

There was a strong consensus from both owner-managers and employees that on-the -job learning through undertaking project-work was vital. However, extracurricular networking, often outside business hours, was expected, encouraged and rewarded. 
For example, at CommCo, group events organized through the firm's social committee represented an important means of encouraging employees to make important professional connections and build their personal network of contacts. This was deemed by the owner-managers as a vital 'back to basics' method to help junior consultants learn what it takes to be a good PR person and to cultivate their relationship building and networking skills:

...there is tab behind the bar and there is night out but there is a prize for whoever makes the best contact the next day ... whoever produces the hot business card or whatever (Owner-manager 1, CommCo).

While employees were acutely aware of the benefit of such events, they expressed some reservations about having to work long hours on top of 'juggling' existing clients during the day. However, the strong commitment of employees to their owner-managers made them reluctant to do anything that would 'let the side down'. As an employee from PeopleCo observed:

They are absolutely brilliant. They are your bosses and they will put down the foot when it needs to be but I have such a massive respect for them I would never go out of line anyway (Relationship Manager, PeopleCo).

All employees highlighted the important role that project teams played in their learning and development; before, during and following project completions:

My colleagues are very important because only for them I wouldn't be able to do the job that I am doing. We really are a team. We really do support each other (Junior consultant, MultiCo).

Thus, there was a significant level of responsibility for HRD that was delegated to employees and it was incumbent upon them to share knowledge with others, as well as to maximize opportunities to enhance their skills. Formal mechanisms such as staff meetings and the performance review process provided a forum for employees to express their needs and reflect on their learning experiences. However, these mechanisms also served as a forum for consultation around owner-manager and employee expectations about the HRD process, including the sharing of knowledge. While employees readily embraced this feature of their work, owner-managers acknowledged that not all employees had the KSAs to train others, which raised the question of inappropriate habits or work behaviours being passed on.

\section{Impact of network influences on HRD within small PSFs}

The combined influence and resource value of both external and internal networks resulted in unique approaches to $\mathrm{HRD}$ in the firms studied. Fundamentally, the approach to HRD was flexible and dynamic, and characterised by combinations of formality and informality. This allowed the firms to tailor their HRD efforts to meet dynamic client needs. Given the centrality of interpersonal skills to effective role performance, owner-managers and employees tended to extol the virtues of informal, on-the-job interventions as being of greater relevance to skill acquisition and having a more positive impact on job performance: 
...a lot of the work and the performance of the individuals here would come from that tacit knowledge place in which the learning is experiential; it's a sitting-with-nelly approach and listening to what's going on (Owner-manager, MultiCo).

I would say on-the-job definitely. The stuff away from work helps but it is definitely listening to people and learning from people as you're going along (Senior account manager, MultiCo).

However, aspects of formality also emerged. Examples of where this was manifest was in the presence of HRD policies, HRD budgets, the use of written HRD plans and the delivery of HRD off-the-job by external personnel. The introduction of the formal CPD programme at PeopleCo could also be regarded as a strategic response to client influences. This programme in turn triggered the introduction of an organizational database which was widely regarded as an important knowledge repository. A similar database was introduced at CommCo, while at MultiCo, the firm was relying more on peer-to-peer knowledge exchange. However, the personal philosophy of the owner-manager was also important. At PeopleCo and MultiCo, the owner-managers viewed the ETP standard as a means to systematize and integrate all internal HRD activities and create a more formal approach. ETP certification had prompted a review of HRD policies and procedures at all firms, as well as the introduction of a staff handbook at PeopleCo. At PeopleCo, the task of applying for the standard had been assigned to one of the first company graduates to be taken on by the firm. The application had prompted the development of a staff handbook and safety statement but was regarded more as a means of documenting what was already taking place. However, employees found it difficult to articulate what the standard involved and were unaware of how it impacted on HRD in the firm more generally and on their personal learning and development.

Similarly, at MultiCo, while employees acknowledged that the owner-manager was very proud of the company's achievement of the standard, it meant very little to them in terms of its influence on their daily work. They spoke in largely negative terms about ETP, primarily due to its bureaucratic nature and overriding need to document all facets of HRD. The owner-manager also admitted that ETP record keeping had been neglected in recent months due to operational pressures. He expressed concern about out of date documentation, as well as the disconnect between individual training plans and the HRD that was currently happening at the company:

We started down the path of having ETP and over the period of 11 years there's been highs and lows of when it's been in very good condition and when it wasn't in very good condition, at the moment it would be very poor. It would be very poor largely because we hadn't even thought about the subject since this time last year. We're in a mode of struggling for survival (Owner-manager, MultiCo).

A further key response to network influences in the case firms was the deliberate integration of HRD with other key HRM practices, namely recruitment, selection and performance management. Great care was taken in MultiCo to select the 'right' employees and many permanent staff were known to the owner-manager or had previously worked for the firm in an associate capacity. Cultural fit was also deemed vital at PeopleCo and a deliberate policy of recruiting University-educated employees and 
moulding them in a manner consistent with the firm's culture was the preferred approach. In addition, at PeopleCo and CommCo, the performance management process provided employees with a structured framework to identify and discuss their learning and development needs with owner-managers. Thus HRD practices coalesced with a range of HRM practices to meet the needs of both the employees and the firm.

\section{Discussion}

The question of the networks that owner-managers of small PSFs use to acquire important resources for HRD is one that stimulates interest among HRD scholars and practitioners (Ahuja et al. 2009; Hubner and Baum 2018). Building on the general idea that ownermanagers can utilize networks to acquire resources beneficial to the achievement of HRD, we offer insights into both the types of networks and their extensiveness, as well as the type of resources they generate. Findings from a sample of small management consulting firms revealed that owner-managers utilize a combination of internal and external networks to secure HRD resources and address dynamic HRD priorities. These networks generated both explicit and tacit HRD resources that can be categorized as systemic, socio-political and strategic. Our theory and findings therefore enrich both network and RDT explanations and research on networks in the context of small firms and HRD. Next we discuss the contribution and research implications of our findings as well as their HRD practice implications.

\section{Implications for research}

First, consistent with earlier studies that have revealed the important role of networks in the context of SMEs to achieve a variety of goals including innovation (Iturrioz, Aragón, and Narvaiza 2015), learning (Saunders, Gray, and Goregaokar 2014) and ambidexterity (Heavey, Simsek, and Fox 2015), our findings point to the value of having extensive internal and external networks to generate different types of resources for HRD. Such findings are therefore suggestive of the idea that important components of knowledge and expertise required for HRD are socially embedded in networks. This is an important finding given the resource scarcity experienced by small PSFs and suggests that they will acquire significant resource benefits from cultivating networks that are an appropriate fit with the resource requirements of a small PSF (Bishop 2011; Doherty and Norton 2014). These networks may indeed help small PSFs overcome their resource deficiencies. Our findings additionally suggested that these networks will change given the dynamic HRD priorities of small PSFs (Úbeda-García et al. 2017). Scholars highlight that it is the extensiveness of the SME network that is important or the strength of the full set of internal and external networks (Heavey, Simsek, and Fox 2015; Lin et al. 2009). Our findings indicated that an appropriate network will include relationships that involve frequent, long-term and emotionally intense interactions. This finding is consistent with Granovetter's (1973) concept of strong ties and with previous research (Reagans and McEvily 2003; Moran 2005), which indicates that networks characterised by frequent, long duration and emotionally intense interactions will provide owner-managers of small PSFs with valuable tacit knowledge and insights and enable access to complex knowledge types. 
Second, we enrich the research base by revealing the types of networks that are valuable to achieve HRD priorities. Our findings suggested two types of external networks. First, there are those which can be labelled coercive networks (Bacon and Hoque 2005; Wu, Bacon, and Hoque 2014) in the form of networks with clients (Fosstenløkken, Løwendahl, and Revang 2003). RDT emphasizes how the power embedded in the client-consultant relationship can shape how HRD is undertaken (Hillman et al. 2009). Our study therefore builds on previous research in relation to the value of clients for resources in helping small PSFs achieve HRD priorities (Hillman et al. 2009; Kinnie et al. 1999). Clients played a major role in resource provision and may help small PSFs in their use of sophisticated HRD approaches, as well as contributing to developing the skills and behaviour of employees within the firm. Client influences were found to be both direct and indirect. We also found evidence of the resource role of advisory networks in the form professional bodies and business contacts (Erickson and Jacoby 2003; Hoque and Bacon 2006). Consistent with the RDT perspective, small PSFs had significant discretion as regards their utilization of these networks and their degree of engagement with them, resulting in a much more ad-hoc networking approach. In addition, small PSF owner-managers made use of informal advisory networks or trusted external contacts (Bishop 2011; Hubner and Baum 2018). These networks were used on a reactive and ad-hoc basis to solve problems that arose during client interactions and they represented an important source of tacit knowledge.

Third, our findings are revealing when it comes to the types of internal networks that are important. We found evidence of the network role of employees, the ownermanager, interdependencies between employees and the owner-manager, and personal contacts within the small PSF. The notion of employees as a source of resources points to their co-creation role in developing HRD solutions as well as implementing them (Voss and Brettel 2014). The role of the employee in the delivery of HRD and as a network resource of value to the small firm is significantly underplayed in the literature. Our findings suggest a model of HRD delivery that is collaborative and envisages the employee, who is typically the target of HRD, as both a producer and deliverer of HRD.

Our findings in respect of the owner-manager as an important mobilizer of resources in the context of internal and external networks also represent an important contribution (Barrett 2015; McClean and Collins 2011). Owner-managers brought energy, enthusiasm, commitment and conviction to implementing HRD in small PSFs, which was reciprocated by employees in the form of enhanced discretionary effort (Mallett and Wapshott 2014). Of particular note is the interdependence between ownermanagers and employees (Bendickson et al. 2016). Owner-managers at all three firms were hands-on in terms of providing their expertise via on-the-job training, informal mentoring and guidance to employees on a daily basis. Such practices were embraced due to the flexibility they bestowed upon the firms to adapt to evolving client demands (Verreynne et al. 2013), as well as enabling the firms to manage the financial constraints associated with external HRD. We also found that interdependencies between ownermanagers and employees were bidirectional; employees relied on owner-managers providing access to learning opportunities, notably through mentoring relationships, to facilitate their development as consultants (Hitt et al. 2001; Wapshott and Mallett 
2013). In turn, owner-managers relied heavily on the employee skill-mix to deliver a high quality client service (Bacon and Hoque 2005; Wu, Bacon, and Hoque 2014). Such interdependencies between employees were also critical as effective service delivery required them to combine their efforts, skill, expertise and knowledge in a coordinated way (Løwendahl 2005).

A final internal network that is important in the context of HRD and resources is the use of internal personal contacts. These included key managers or friends within the small PSF who were a source of advice and counsel. These networks varied in terms of formality and were more ad-hoc and reactive in terms of use (Bishop 2011). All of the internal networks that emerged from our research were also contextualised by the small PSFs' human and organizational capital.

Fourth, we enrich current research findings by revealing the types of resources that emerged from the use of networks. We found that small PSFs derived three types of knowledge in different amounts from networks (Evans and Easterby-Smith 2001), including systemic, socio-political and strategic resources. Clients for example provided all three type of knowledge including questioning small PSFs about how HRD should be undertaken, providing tacit advice and information, shaping employee behaviours and developing critical interpersonal skills and helping firms to achieve certification (Anderson-Gough et al. 2000; Hubner and Baum 2018). External advisory networks provided information or advice about HRD opportunities, as well as providing useful learning events (Erickson and Jacoby 2003). Employees provided important resources for HRD including their expertise in coaching others (Voss and Brettel 2014), their knowledge resources derived from networking (Hargadon and Bechky 2006), and their use of learning opportunities to develop the tacit knowledge of the firm (Mallett and Wapshott 2014). Employees also engaged in peer learning via project-based interactions and endeavoured to solve particular problems through peer discussion. Post-project team briefings were important mechanisms that fostered learning and ultimately improved business processes (Fosstenløkken et al. 2003; Werr 2012).

Based on our empirical analysis we propose a conceptual framework (Figure 2) to depict our findings. We highlight the three categories of external and four categories of internal networks that emerged in our study. In the centre of the framework we categorize the HRD resources generated through these networks. Each category includes both explicit and tacit dimensions. The first category, systemic HRD resources, refers to knowledge embedded in client and PSF policies, processes, procedures and systems. These explicit components are less common with the small PSF, however, they are more common with the client. There is significant evidence of tacit systemic knowledge including insights into how to approach HRD, the types of shortcuts that can be taken, why things are done in particular ways and desired employee behaviours in the context of the consulting relationship. Sociopolitical HRD knowledge derived from networks concerns, roles, people, capabilities and processes required to deliver client solutions. Tacit dimensions include knowledge of who is influential when it comes to development, what types of HRD approaches are preferred, how to get HRD done effectively and norms around the delivery of HRD. Strategic HRD resources focus on explicit plans, visions and approaches to $\mathrm{HRD}$ as well as tacit dimensions including gauging client expectations, utilizing developmental relationships and knowledge of the tacit competencies of 


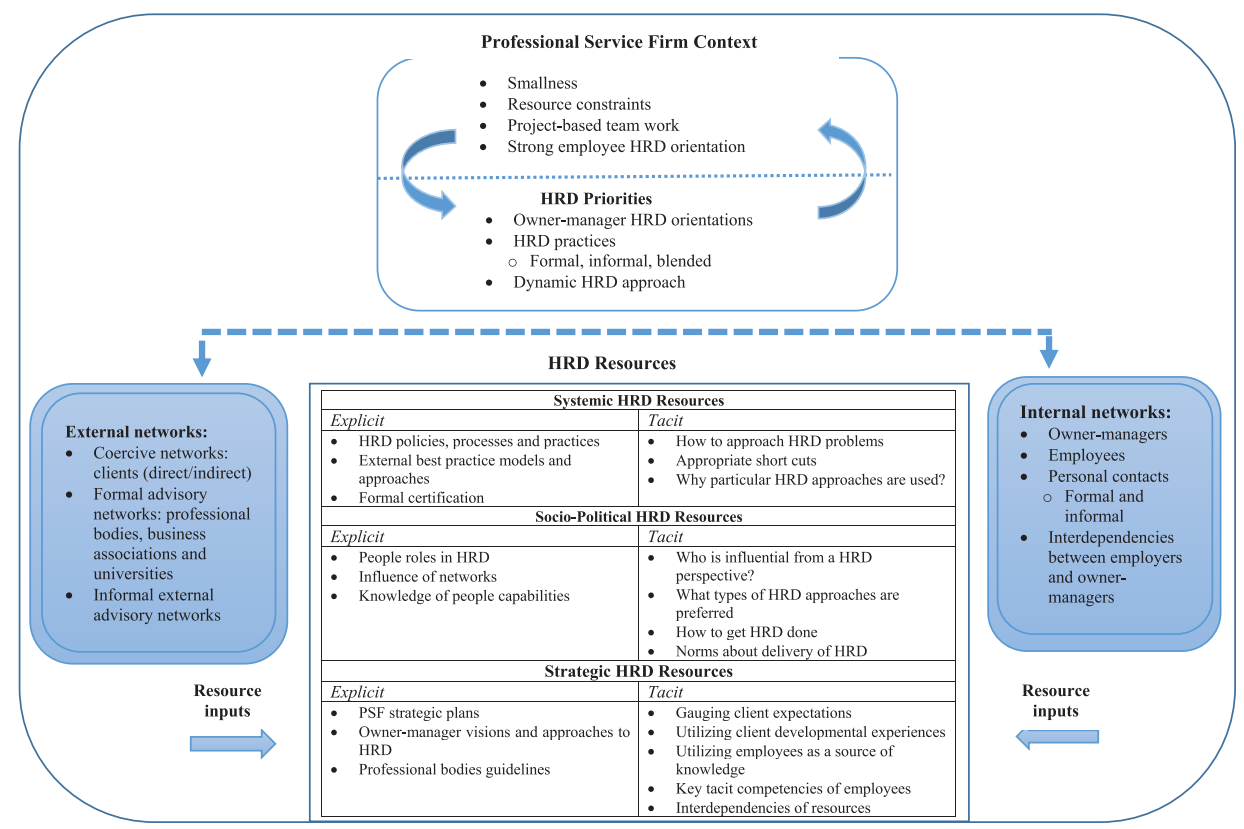

Figure 2. Conceptual framework: external and internal networking and resources for HRD in small PSFs.

employees. The framework also highlights the PSF context and the interdependencies between internal and external networks.

\section{Practical implications}

Our results have a number of implications for HRD practice. It is clear from the findings that there are benefits in small PSFs making use of both external and internal networks to secure different categories of resources for HRD. An appropriate networking strategy may help owner-managers enhance their resource provision for HRD. Therefore, owner-managers should be aware of these network advantages and their impact on resource dependency. They should also focus on developing diverse formal and informal networks and encourage employees to do the same. The extent and nature of the required networks to address HRD priorities may also change over time. Ownermanagers therefore need to be fully cognisant that the development of network relationships must be an ongoing activity embedded in their modus operandi.

The central role of employees in providing resources for HRD is a particularly salient finding from our research. Employees can, through their behaviours and actions, help address many of the HRD priorities of small PSFs. In particular, they can provide coaching, peer learning and help these firm build an important tacit knowledge resource. Therefore, it is important that owner-managers utilize an appropriate leadership style in order to maximise these resource contributions. It is also imperative that the optimum skill-mix is acquired, developed and maintained in order to ensure high standards of service delivery. As client interactions trigger 
learning, careful thought needs to be given to the composition of project teams, the organization of work and the allocation of duties. Given the relative power of employees, consultation and dialogue about future learning and development opportunities would also appear to be vital.

\section{Limitations and directions for future research}

The findings should be viewed in the light of the limitations of this study, which also provide opportunities for future research. First, we conducted our research within one type of firm - PSFs - and the small sample size is an issue. Hence, caution is warranted when considering the applicability of our findings to other firms. However, given the exploratory and qualitative nature of our study, we did not seek generalization. We focused on the transferability of our findings by providing rich descriptions of the firms and their context (Lincoln and Guba 1985). We believe that our study is an important first step in utilizing RDT and network theories to understand the role of external and internal networks in providing resources for HRD. The use of a qualitative case study approach is a strength of our study, however, future studies can develop hypotheses for testing using survey methods. In addition, given that we examined small PSFs located with the Republic of Ireland, we cannot make assumptions about the experiences of firms operating in different cultural contexts.

Second, while we used archival data and documents they did not allow us to capture the decision-making processes in respect of external and internal network actors. Therefore future research can utilize qualitative, longitudinal methodologies to advance our knowledge of these decisions. In addition, it is important to understand how access to network actors changes over time and their relative importance as the small PSF grows. It is vital to understand when and how networks change over time. These dimensions can best be understood through interviewing owner-managers, network actors and those who have been involved in HRD decision-making processes.

Third, in this study we only examined the owner-manager and employee perspectives on the resource benefits of various actors in the context of HRD. Therefore, future research can engage in a more extensive investigation of the perspectives of external actors and more fully understand the importance of interdependencies in those actors' relationships (cf. Donnelly 2011). These actors include clients, professional bodies and trade unions. The part that clients play as co-producers of HRD is a significant finding of this study, as much of the learning of consultants takes place as a by-product of client work; before, during and following project completions. However, as Fosstenløkken et al. $(2003,876)$ observe, "it is not obvious that the clients who are "right" from an operational or profit-maximisation point of view, are always the same as the clients who are "right" from a knowledge-development point of view'. Thus, it is vital that future research explores which client characteristics facilitate or inhibit HRD in small PSFs.

\section{Conclusion}

This paper presents an exploratory study illustrating the role of networks in generating resources to realize HRD priorities in small PSFs. The study findings reveal that small PSFs derive important resources from an extensive set of internal and external 
networks. The paper provides insights into the types of systemic, socio-political and strategic HRD resources that are accumulated through networking. In terms of theory and research implications our findings are suggestive of the value of integrating both network and RDT perspectives in the context of understanding access to HRD resources. In the practical arena, the study findings highlight the critical importance of clients in generating different types of resources for HRD and the role of employees who also provide vital HRD resources. We suggest that further research is needed to understand how HRD may be influenced by interdependencies between networks, the role of networks and resources over time and the impact of networks and resources on small PSF performance.

\section{Notes}

1. Skillnets is an Irish national agency with responsibility for promoting workplace learning through training networks.

2. SOLAS is a state agency with responsibility for funding, planning and co-ordinating Further Education and Training (FET) in Ireland.

\section{Disclosure statement}

No potential conflict of interest was reported by the authors.

\section{References}

Ahuja, G., F. Polidoro, and W. Mitchell. 2009. "Structural Homophily or Social Asymmetry? the Formation of Alliances by Poorly Embedded Firms." Strategic Management Journal 30 (9): 941-958. doi:10.1002/smj.774.

Anderson-Gough, F., C. Grey, and K. Robson. 2000. "In the Name of the Client: The Service Ethic in Two Professional Services Firms." Human Relations 53 (9): 1151-1174. doi:10.1177/ 0018726700539003.

Awuah, G. B. 2007. “A Professional Services Firm's Competence Development.” Industrial Marketing Management 36 (8): 1068-1081. doi:10.1016/j.indmarman.2006.08.006.

Bacon, N., and K. Hoque. 2005. "HRM in the SME Sector: Valuable Employees and Coercive Networks." International Journal of Human Resource Management 16 (11): 1976-1999. doi:10.1080/09585190500314706.

Barrett, R. 2015. "Small Firm Training: Just Meeting the Day-To-Day Needs of the Business." Employee Relations 37 (5): 547-567. doi:10.1108/ER-05-2014-0048.

Barringer, B. R., and J. S. Harrison. 2000. "Walking a Tightrope: Creating Value through Interorganizational Relationships.” Journal of Management 26 (3): 367-403. doi:10.1177/ 014920630002600302.

Behrends, T. 2007. "Recruitment Practices in Small and Medium Enterprises: An Empirical Study among Knowledge- Intensive Professional Service Firms." Management Revue 18 (1): 55-74. doi:10.5771/0935-9915-2007-1-55.

Bendickson, J., F. A. Gur, and E. C. Taylor. 2016. "Reducing Environmental Uncertainty: How High Performance Work Systems Moderate the Resource Dependence-Firm Performance Relationship." Canadian Journal of Administrative Sciences. doi:10.1002/CJAS.1412.

Bishop, D. 2011. “The Importance of Being an Insider: How Networks Influence the Small Firm's Engagement with Formal Training." Journal of European Industrial Training 35 (4): 326-344. doi:10.1108/03090591111128315. 
Broschak, J. P. 2017. "Client Relationships in Professional Service Firms." In The Oxford Handbook of Professional Service Firms, edited by L. Empson, D. Muzio, J. P. Broschak, and B. Hinnings, 304-326. Oxford: Oxford University Press.

Brown, A. D., M. Kornberger, S. R. Clegg, and C. Carter. 2010. "Invisible Walls' and 'Silent Hierarchies': A Case Study of Power Relations in an Architecture Firm.” Human Relations 63 (4): 525-549. doi:10.1177/0018726709339862.

Carbery, R. 2015. "Introduction to HRD." In Human Resource Development: A Concise Introduction, edited by R. Carbery and C. Cross, 1-28. Basingstoke: Palgrave.

Cassell, C., S. Nadin, M. Gray, and C. Clegg. 2002. "Exploring Human Resource Practices in Small and Medium Sized Enterprises." Personnel Review 31 (5/6): 671-693. doi:10.1108/ 00483480210445962.

Chang, S. J. 2004. "Venture Capital Financing, Strategic Alliances, and the Initial Public Offerings of Internet Startups." Entrepreneurship Theory and Practice 19 (5): 721-741. doi:10.1016/j. jbusvent.2003.03.002.

Collis, J., and R. Hussey. 2014. Business Research (4th ed.). Basingstoke: Palgrave Macmillan.

Curran, J., and A. Blackburn. 2001. Researching the Small Enterprise. London: Sage.

Denzin, N. K. 1978. Sociological Methods: A Sourcebook. (2nd.). New York: McGraw Hill.

Dietz, G., T. van der Wiele, J. van Iwaarden, and J. Brosseau. 2006. "HRM inside UK E-Commerce Firms: Innovations in the 'New' Economy and Continuities with the 'Old'." International Small Business Journal 24 (5): 443-470. doi:10.1177/0266242606067267.

Doherty, L., and A. Norton. 2014. "Making and Measuring 'Good' HR Practice in an SME: The Case of a Yorkshire Bakery.” Employee Relations 36 (2): 128-147. doi:10.1108/ER-02-20130017.

Donnelly, R. 2011. "Synergies and Conflict of Interest in Consultancy." Human Resource Management Journal 21 (1): 60-73. doi:10.111/j.1748-8583.2010.00130.x.

Drakopoulou Dodd, S., and E. Patra. 2002. "National Differences in Entrepreneurial Networking." Entrepreneurship \& Regional Development 14 (2): 117-134. doi:10.1080/ 08985620110111304.

Eisenhardt, K. M. 1989. "Making Fast Strategic Decisions in High-velocity Environments." Academy of Management Journal 32 (3): 543-576. doi: 10.5465/256434.

Erickson, C. L., and S. M. Jacoby. 2003. "The Effect of Employer Networks on Workplace Innovation and Training." Industrial and Labor Relations Review 56 (2): 203-224. doi:10.2307/3590935.

European Commission. 2015. User Guide to the SME Definition. Luxembourg: Publications Office of the European Union.

Evans, N., and M. Easterby-Smith. 2001. "Three Types of Organizational Knowledge: Implications for the Tacit-Explicit and Knowledge Creation Debates.” In Organizational Learning and Knowledge Management, edited by M. Crossan and F. Olivera, 135-154. London: University of Western Ontario.

Fincham, R. 2012. "The Client in the Client-Consultant Relationship." In The Oxford Handbook of Management Consulting, edited by M. Kipping and T. Clark, 411-426. Oxford: Oxford University Press.

Forth, J., H. Bewley, and A. Bryson. 2006. Small and Medium-Sized Enterprises: Findings from the 2004 Workplace Employment Relations Survey. London: Department of Trade and Industry.

Fosstenløkken, S. M., B. R. Løwendahl, and Ø. Revang. 2003. “Knowledge Development through Client Interaction: A Comparative Study.” Organization Studies 24 (6): 859-879. doi:10.1177/ 0170840603024006003.

Fox, H. L. 2013. "Strategic Human Resource Development in Small Businesses in the United States." Academy of Entrepreneurship Journal 19 (1): 77-118.

Fu, N., P. C. Flood, J. Bosak, T. Morris, and P. O’Regan. 2015. "How Do High Performance Work Systems Influence Organizational Innovation in Professional Service Firms?” Employee Relations 37 (2): 209-231. doi:10.1108/ER-10-2013-0155.

George, C. 2015. "Retaining Professional Workers: What Makes Them Stay?" Employee Relations 37 (1): 102-121. doi:10.1108/ER-10-2013-0151. 
Ghosh, R., M. Kim, S. Kim, and J. L. Callahan. 2014. "Examining the Dominant, Emerging, and Waning Themes Featured in Select HRD Publications: Is It Time to Redefine HRD?" European Journal of Training and Development 38 (4): 302-322. doi:10.1108/EJTD-02-2013-0012.

Giauque, D., F. Resenterra, and M. Siggen. 2010. “The Relationship between HRM Practices and Organizational Commitment of Knowledge Workers. Facts Obtained from Swiss SMEs." Human Resource Development International 13 (2): 185-205. doi:10.1080/ 13678861003703716.

Gibb, A. A. 1993. "The Enterprise Culture and Education. Understanding Enterprise Education and Its Links with Small Business, Entrepreneurship and Wider Educational Goals." International Small Business Journal 11 (3): 11-37. doi:10.1177/026624269301100301.

Gibb, A. A. 2000. "SME Policies, Academic Research and the Growth of Ignorance. Mythical Concepts, Myths, Assumptions, Rituals and Confusions.” International Small Business Journal 18 (3): 13-36. doi:10.1177/0266242600183001.

Gibb, A. A. 2009. "Meeting the Development Needs of Owner Managed Small Enterprise: A Discussion of the Centrality of Action Learning." Action Learning: Research and Practice 6 (3): 209-227. doi:10.1080/14767330903299415.

Gilman, M., P. Edwards, M. Ram, and J. Arrowsmith. 2002. "Pay Determination in Small Firms in the UK: The Case of the Response to the National Minimum Wage." Industrial Relations Journal 33 (1): 52-67. doi:10.1111/1468-2338.00219.

Gioia, D. A., K. G. Corley, and A. L. Hamilton. 2013. "Seeking Qualitative Rigor in Inductive Research: Notes on the Gioia Methodology." Organizational Research Methods 16 (1): 15-31. doi:10.1177/1094428112452151.

Gordon, I., and S. Jack. 2010. "HEI Engagement with SMEs: Developing Social Capital." International Journal of Entrepreneurial Behaviour \& Research 16 (6): 517-539. doi:10.1108/ 13552551011082489.

Granovetter, M. 1973. "Strength of Weak Ties.” American Journal of Sociology 78 (6): 1360-1380.

Gray, D. E. 2017. Doing Research in The Business World. London: Sage.

Hargadon, A. B., and B. A. Bechky. 2006. "When Collections of Creatives Become Creative Collectives: A Field Study of Problem Solving at Work." Organization Science 17 (4): 484-500. doi:10.1287/orsc. 1060.0200 .

Harney, B., and T. Dundon. 2006. "Capturing Complexity: Developing an Integrated Approach to Analysing HRM in SMEs." Human Resource Management Journal 16 (1): 48-73. doi:10.1111/j.1748-8583.2006.00004.x.

Heavey, C., Z. Simsek, and B. C. Fox. 2015. "Managerial Social Networks and Ambidexterity of SMEs: The Moderating Role of a Proactive Commitment to Innovation." Human Resource Management 54 (S1): s201-s221. doi:10.1002/hrm.21703.

Henry, C., and L. Foss. 2015. "Case Sensitive? A Review of the Literature on the Use of Case Method in Entrepreneurship Research." International Journal of Entrepreneurial Behavior \& Research 21 (3): 389-409. doi: 10.1108/IJEBR-03-2014-0054.

Hillman, A. J., M. C. Withers, and B. J. Collins. 2009. "Resource Dependence Theory: A Review." Journal of Management 25 (6): 1404-1427. doi:10.1177/0149206309343469.

Hirschsohn, P. 2008. "Regulating the 'Animal Spirits' of Entrepreneurs? Skills Development in South African Small and Medium Enterprises.” International Small Business Journal 26 (2): 181-206. doi:10.1177/0266242607086573.

Hite, J. M. 2005. "Evolutionary Processes and Paths of Relationally Embedded Network Ties in Emerging Entrepreneurial Firms.” Entrepreneurship Theory and Practice 29 (1): 113-144. doi:10.1111/j.1540-6520.2005.00072.x.

Hitt, M. A., L. Bierman, K. Shimizu, and R. Kochhar. 2001. "Direct and Moderating Effects of Human Capital on Strategy and Performance in Professional Service Firms: A Resource-Based Perspective." Academy of Management Journal 44 (1): 13-28. doi:10.2307/3069334.

Hoque, K., and N. Bacon. 2006. "The Antecedents of Training Activity in British Small and Medium- Sized Enterprises.” Work, Employment and Society 20 (3): 531-552. doi:10.1177/ 0950017006067000 . 
Hubner, S. V., and M. Baum. 2018. "Entrepreneurs' Human Resources Development.” Human Resource Development Quarterly 1-25. doi:10.1002/hrdq.21328.

Iturrioz, C., C. Aragón, and L. Narvaiza. 2015. "How to Foster Shared Innovation within SMEs' Networks: Social Capital and the Role of Intermediaries." European Management Journal 33 (2): 104-115. doi:10.1016/j.emj.2014.09.003.

Jack, S. J. 2010. “Approaches to Studying Networks: Implications and Outcomes." Journal of Business Venturing 25 (1): 120-137. doi:10.1016/j.jbusvent.2008.10.010.

Jones, J. 2006. "An Inter-Industry Comparison of VET in Australian SMEs: Inter-Industry Comparison." Education + Training 48 (8/9): 584-596. doi:10.1108/00400910610710029.

Jørgensen, F., and K. Becker. 2015. "Balancing Organizational and Professional Commitments in Professional Service Firms: The HR Practices that Matter." The International Journal of Human Resource Management 26 (1): 23-41. doi:10.1080/09585192.2014.925947.

Kinnie, N., J. Purcell, S. Hutchinson, M. Terry, M. Collinson, and H. Scarbrough. 1999. "Employment Relations in SMEs: Market-Driven or Customer-Shaped?" Employee Relations 21 (3): 218-235. doi:10.1108/01425459910273071.

Kinnie, N., J. Swart., and J. Purcell. 2005. "Influences on the Choice of HRM Systems: The Network Organization Perspective." International Journal of Human Resource Management 16 (6): 1004-1028. doi:10.1080/09585190500120780.

Kipping, M., and T. Clark. 2012. "Researching Management Consulting: An Introduction to the Handbook." In The Oxford Handbook of Management Consulting, edited by M. Kipping and T. Clark, 1-26. Oxford: Oxford University Press.

Klaas, B. S., M. Semadeni, M. Klimchak, and A.-K. Ward. 2012. "High-Performance Work System Implementation in Small and Medium Enterprises: A Knowledge-Creation Perspective." Human Resource Management 51 (4): 487-510. doi:10.1002/hrm.21485.

Kroon, B., K. Van De Voorde, and J. Timmers. 2013. "High Performance Work Practices in Small Firms: A Resource-poverty and Strategic Decision-making Perspective.” Small Business Economics 41 (1): 71-91. doi: 10.1007/s11187-012-09425-0.

Kuzel, A. 1992. "Sampling in Qualitative Inquiry." In Doing Qualitative Research, edited by B. Crabtree and W. Miller, 31-44. Newbury Park, CA: Sage.

Lam, L. W., and L. P. White. 1998. "Human Resource Orientation and Corporate Performance." Human Resource Development Quarterly 9 (4): 351-364. doi:10.1002/hrdq.3920090406.

Lawrence, T. B., N. Malhotra, and T. Morris. 2012. "Episodic and Systemic Power in the Transformation of Professional Service Firms." Journal of Management Studies 49 (1): 102-143. doi:10.1111/j.1467-6486.2011.01031.x.

Leung, A., J. Zhang, P. K. Wong, and M. D. Foo. 2006. "The Use of Networks in Human Resource Acquisition for Entrepreneurial Firms: Multiple 'Fit' Considerations.” Journal of Business Venturing 21 (5): 664-684. doi:10.1016/j.jbusvent.2005.04.010.

Lin, Z., M. W. Peng, H. Yang, and S. L. Sun. 2009. "How Do Networks and Learning Drive M\&As? an Institutional Comparison between China and the United States." Strategic Management Journal 30 (10): 1113-1132. doi:10.1002/smj.777.

Lincoln, Y., and E. Guba. 1985. Naturalistic Inquiry. Beverly Hills, CA: Sage.

Løwendahl, B. R. 2005. Strategic Management of Professional Service Firms (3rd ed.). Copenhagen: Copenhagen Business School Press.

Maister, D. H. 1993. Managing the Professional Service Firm. New York: Free Press.

Mallett, O., and R. Wapshott. 2014. "Informality and Employment Relationships in Small Firms: Humour, Ambiguity and Straight-Talking." British Journal of Management 25 (1): 118-132. doi:10.1111/j.1467-8551.2012.00836.x.

McClean, E., and C. J. Collins. 2011. "High-Commitment HR Practices, Employee Effort, and Firm Performance: Investigating the Effects of HR Practices across Employee Groups within Professional Services Firms." Human Resource Management 50 (3): 341-363. doi:10.1002/ hrm.20429.

Mehra, A., A. L. Dixon, D. J. Brass, and B. Robertson. 2006. “The Social Network Ties of Group Leaders: Implications for Group Performance and Leader Reputation.” Organization Science 17 (1): 64-79. doi:10.1287/orsc.1050.0158. 
Messersmith, J. G., and W. J. Wales. 2011. "Entrepreneurial Orientation and Performance in Young Firms: The Role of Human Resource Management.” International Small Business Journal 31 (2): 115-136. doi:10.1177/0266242611416141.

Miles, M. B., and M. A. Huberman. 1994. Qualitative Data Analysis. 2nd ed. California: Sage.

Moran, P. 2005. "Structural Vs. Relational Embeddedness: Social Capital and Managerial Performance." Strategic Management Journal 26: 1129-1151. doi:10.1002/smj.486.

Morris, T. 2001. "Asserting Property Rights: Knowledge Codification in the Professional Service Firm.” Human Relations 54 (7): 819-838. doi:10.1177/0018726701547002.

Morris, T., and L. Empson. 1998. "Organization and Expertise: An Exploration of Knowledge Bases and the Management of Accounting and Consulting Firms." Accounting, Organizations and Society 23 (5-6): 609-624. doi:10.1016/S0361-3682(98)00032-4.

Nolan, C. T., and T. N. Garavan. 2016. "Human Resource Development in SMEs: A Systematic Review of the Literature." International Journal of Management Reviews 18 (1): 85-107. doi:10.1111/ijmr.12062.

Oczan, O., and K. M. Eisenhardt. 2009. "Origin of Alliance Portfolios: Entrepreneurs, Network Strategies, and Firm Performance.” Academy of Management Journal 52 (2): 246-279. doi:10.5465/amj.2009.37308021.

Padachi, K., and S. L. Bhiwajee. 2016. "Barriers to Employee Training in Small and Medium Sized Enterprises." European Journal of Training and Development 40 (4): 232-247. doi:10.1108/EJTD-02-2014-0018.

Patton, M. Q. 1990. Qualitative Evaluation and Research Methods. 2nd ed. Newbury Park, CA: Sage.

Patton, M. Q. 2002. Qualitative Evaluation and Research Methods. 3rd ed. Newbury Park, CA: Sage.

Pfeffer, J., and G. R. Salancik. 1978. The External Control of Organizations: A Resource Dependence Perspective. New York: Harper and Row.

Pratt, M. G. 2008. "Fitting Oval Pegs into Round Holes: Tensions in Evaluating and Publishing Qualitative Research in Top-Tier North American Journals." Organizational Research Methods 11 (3): 481-509. doi:10.1177/1094428107303349.

Ram, M. 2000. "Investors in People in Small Firms: Case Study Evidence from the Business Services Sector.” Personnel Review 29 (1): 69-91. doi:10.1108/00483480010295826.

Ram, M., K. Woldesenbet, and T. Jones. 2011. "Raising The 'Table Stakes'? Ethnic Minority Businesses and Supply Chain Relationships.” Work Employment and Society 25 (2): 309-326. doi: 10.1177/0950017011398896.

Reagans, R., and B. McEvily. 2003. "Network Structure and Knowledge Transfer: The Effects of Cohesion and Range." Administrative Science Quarterly 48 (2): 240-267. doi:10.2307/3556658.

Ridder, H. G., C. Hoon, and A. McCandless Baluch. 2014. "Entering a Dialogue: Positioning case Study Findings Towards Theory." British Journal of Management 25 (2): 373-387. doi: 10.1111/1467-8551.12000.

Saunders, M. K., D. E. Gray, and H. Goregaokar. 2014. "SME Innovation and Learning: The Role of Networks and Crisis Events." European Journal of Training and Development 38 (1/2): 136-149. doi:10.1108/EJTD-07-2013-0073.

Short, H. J., and D. E. Gray. 2018. "HRD in SMEs: A Research Agenda Whose Time Has Come." Human Resource Development Quarterly 29 (1): 7-13. doi:10.1002/hrdq.21305.

Storberg-Walker, J., and C. Gubbins. 2007. "Social Networks as a Conceptual and Empirical Tool to Understand and 'Do' HRD.” Advances in Developing Human Resources 9 (3): 291-311. doi:10.1177/1523422306304071.

Storey, D. J., and F. J. Greene. 2010. Small Business and Entrepreneurship. New York: FT Prentice Hall.

Sung, S. Y., and J. N. Choi. 2014. "Multiple Dimensions of Human Resource Development and Organizational Performance." Journal of Organizational Behavior 35 (1): 851-870. doi:10.1002/job.1933. 
Susomrith, P., and A. Coetzer. 2015. "Employees' Perceptions of Barriers to Participation in Training and Development in Small Engineering Businesses." Journal of Workplace Learning 27 (7): 561-578. doi:10.1108/JWL-10-2014-0074.

Swart, J., and N. Kinnie. 2003a. "Sharing Knowledge in Knowledge-Intensive Firms." Human Resource Management Journal 13 (2): 60-75. doi:10.1111/j.1748-8583.2003.tb00091.x.

Swart, J., and N. Kinnie. 2003b. "Knowledge-Intensive Firms: The Influence of the Client on HR Systems." Human Resource Management Journal 13 (3): 37-55. doi:10.1111/j.1748-8583.2003. tb00097.x.

Tsai, C. J. 2010. "HRM in SMEs: Homogeneity or Heterogeneity? A Study of Taiwanese High-Tech Firms." The International Journal of Human Resource Management 21 (10): 1689-1711. doi:10.1080/09585192.2010.500490.

Úbeda-García, M., B. Marco-Lajara, V. Sabater-Sempere, and F. García-Lillo. 2013. "Does Training Influence Organizational Performance?" European Journal of Training and Development 37 (4): 380-413. doi:10.1108/03090591311319780.

Úbeda-García, M., E. Claver-Cortés, B. Marco-Lajara, and P. Zaragoza-Sáez. 2017. "Human Resource Flexibility and Performance in the Hotel Industry: The Role of Organizational Ambidexterity.” Personnel Review 46 (4): 824-846. doi:10.1108/PR-12-2015-0315.

van Rooij, S. W., and J. Merkebu. 2015. "Measuring the Business Impact of Employee Learning: A View from the Professional Services Sector." Human Resource Development Quarterly 26 (3): 275-297. doi:10.1002/hrdq.21211.

Vandewelle, D. 1997. "Development and Validation of a Work Domain Goal Orientation Instrument.” Educational and Psychological Measurement 57 (6): 995-1015. doi:10.1177/ 0013164497057006009.

Verreynne, M.-L., P. Parker, and M. Wilson. 2013. "Employment Systems in Small Firms: A Multilevel Analysis.” International Small Business Journal 31 (4): 405-431. doi:10.1177/ 0266242611401445.

Von Nordenflycht, A. 2010. "What Is a Professional Service Firm? toward a Theory and Taxonomy of Knowledge Intensive Firms." Academy of Management Review 35 (1): 155-174. doi:10.5465/AMR.2010.45577926.

Voss, U., and M. Brettel. 2014. "The Effectiveness of Management Control in Small Firms: Perspectives from Resource Dependence Theory." Journal of Small Business Management 52 (3): 569-587. doi:10.1111/jsbm.1205.

Wapshott, R., and O. Mallett. 2013. "The Unspoken Side of Mutual Adjustment: Understanding Intersubjective Negotiation in Small Professional Service Firms.” International Small Business Journal 31 (8): 978-996. doi:10.1177/0266242612450728.

Welsh, J., and J. White. 1981. "A Small Business Is Not A Little Big Business.” Harvard Business Review 59 (4): 18-32. doi:10.1177/026624268200100115.

Werner, J. M. 2014. "Human Resource Development $\neq$ Human Resource Management: So What Is It?” Human Resource Development Quarterly 25 (2): 127-139. doi:10.1002/hrdq.21188.

Werr, A. 2012. "Knowledge as Integration as Heedful Interrelating: Towards a Behavioural Approach to Knowledge Management in Professional Services Firms." In The Handbook of Research on Entrepreneurship in Professional Services, edited by M. Reihlen and A. Werr, 23-41. Cheltenham: Edward Elgar Publishing .

Wu, N., N. Bacon, and K. Hoque. 2014. "The Adoption of High Performance Work Practices in Small Businesses: The Influence of Markets, Business Characteristics and HR Expertise.” The International Journal of Human Resource Management 25 (8): 1149-1169. doi:10.1080/ 09585192.2013.816865.

Yin, R. K. 2014. Case Study Research: Design and Methods(5thed.). Thousand Oaks: Sage. 